\title{
PENJELASAN MENGENAI PATEN DAN SISTEM YANG DITERAPKAN DI INDONESIA MENGENAI PROSES PERMOHONAN HAK PATEN
}

\author{
Dwi Jaya Nugroho \\ 155100021 \\ Fakultas Komputer, 448757191 \\ dwijayanugroho.student@umitra.ac.id
}

\begin{abstract}
Paten adalah perlindungan HKI bagi karya intelektual yang bersifat teknologi, atau dikenal juga dengan istilah invensi, dan mengandung pemecahan/solusi teknis terhadap masalah yang terdapat pada teknologi yang telah ada sebelumnya. Sebagai contoh, paku kecil temuan Levi Strauss untuk dipasang di ujung-ujung saku celana jeans, misalnya, yang kemudian dianugerahi hak paten di Amerika Serikat tahun 1873, mengandung solusi teknis terhadap persoalan mudah lepas/sobeknya jahitan saku celana berbahan denim ketika itu, mengingat pemakaian luar ruangan dengan intensitas yang cukup tinggi.
\end{abstract}

Invensi adalah ide Inventor yang dituangkan ke dalam suatu kegiatan pemecahan masalah yang spesifik di bidang teknologi dapat berupa produk atau proses, atau penyempurnaan dan pengembangan produk atau proses. (UU RI no. 14 tahun 2001, pasal. 1, ayat. 2)

Penerapan pada Hak Paten sendiri diindonesia dinilai dari sistem inventor mendaftarkan produk mereka untuk dipatenkan.

Kata Kunci : Paten Dan Invensi 


\section{A. INTRODUCTION}

\section{Pengertian Paten}

Paten adalah hak eksklusif yang diberikan oleh Negara kepada penemu atas hasil penemuannya di bidang teknologi, yang untuk selama waktu tertentu melaksanakan sendiri Invensinya tersebut atau memberikan persetujuannya kepada pihak lain untuk melaksanakannya. (UU RI no. 14 tahun 2001, ps. 1, ay. 1)

Kata paten, berasal dari bahasa inggris patent, yang awalnya berasal dari kata patere yang berarti membuka diri (untuk pemeriksaan publik), dan juga berasal dari istilah letters patent, yaitu surat keputusan yang dikeluarkan kerajaan yang memberikan hak eksklusif kepada individu dan pelaku bisnis tertentu. Dari definisi kata paten itu sendiri, konsep paten mendorong inventor untuk membuka pengetahuan demi kemajuan masyarakat dan sebagai gantinya, inventor mendapat hak eksklusif selama periode tertentu. Mengingat pemberian paten tidak mengatur siapa yang harus melakukan invensi yang dipatenkan, sistem paten tidak dianggap sebagai hak monopoli.

\section{Yang Berhak Menerima Paten}

Orang yang menghasilkan suatu invensi, baik sendirian maupun beberapa orang bersama-sama, disebut dengan istilah inventor. Inventor inilah yang paling pertama berhak mendapatkan hak paten atas invensi yang dihasilkannya. Siapapun di luar inventor yang ingin memiliki hak paten atas invensi tersebut harus terlebih dahulu memperoleh pengalihan hak secara tertulis dari sang inventor.

Baik Inventor maupun pihak lain yang menerima pengalihan hak dari inventor merupakan Pemilik/Pemegang 
Hak Paten (Patentee), yang memiliki hak eksklusif untuk melaksanakan invensi yang dipatenkan tersebut selama 20 tahun dihitung dari Tanggal Penerimaan. Setelah 20 tahun tersebut, invensi yang dimaksud akan menjadi milik umum (public domain) dan dapat dimanfaatkan oleh siapapun tanpa perlu meminta izin dari si pemegang paten.

\section{Tatacara Dan Prosedur Untuk Mendapatkan Hak Paten}

Sebelum mengajukan permohonan paten, sangat disarankan agar inventor terlebih dahulu melaksanakan penelusuran (search), untuk memperoleh gambaran apakah invensi yang diajukan memang memenuhi syarat kebaruan, artinya belum pernah ada pengungkapan sebelumnya oleh siapapun, termasuk oleh si inventor sendiri. Penelusuran dapat dilakukan terhadap dokumen-dokumen paten baik yang tersimpan pada database DJHKI, maupun kantor-kantor paten lain di luar negeri yang representatif dan juga relevan terhadap teknologi dari invensi yang akan kita patenkan; dan juga terhada dokumendokumen non-paten seperti jurnal-jurnal ilmiah yang terkait.

Penelusuran Paten bahkan sangat disarankan untuk dilakukan sebelum rencana penelitian terhadap suatu teknologi dilaksanakan, demi untuk melakukan technology mapping berdasarkan dokumen paten yang tersedia, sehingga penelitian bisa dilakukan secara lebih efektif dan efisien. Setelah dilakukan penelusuran dan dapat diyakini bahwa invensi yang akan dipatenkan masih mengandung kebaruan, langkah selanjutnya adalah membuat spesifikasi paten, yang terdiri sekurangkurangnya atas:

- Judul Invensi; 
- Latar Belakang Invensi, yang menerangkan teknologi yang ada sebelumnya serta masalah yang terdapat pada teknologi tersebut, yang coba ditanggulangi oleh invensi;

- Uraian Singkat Invensi, yang menerangkan secara ringkas mengenai fitur-fitur yang terkandung dalam, dan menyusun, invensi;

- Uraian Lengkap Invensi, yang menerangkan mengenai bagaimana cara melaksanakan invensi;

- Gambar Teknik, jika diperlukan untuk menerangkan invensi secara lebih jelas;

- Uraian Singkat Gambar, untuk menerangkan mengenai Gambar Teknik yang disertakan;
- Abstrak, ringkasan mengenai invensi dalam satu atau dua paragraf;

- Klaim, yang memberi batasan mengenai fiturfitur apa saja yang dinyatakan sebagai baru dan inventif oleh sang inventor, sehingga layak mendapatkan hak paten.

Penyusunan spesifikasi paten membutuhkan keahlian dan pengalaman tersendiri, karena perlu memadukan antara bahasa teknik dan bahasa hukum di dalamnya. Banyak Konsultan HKI Terdaftar yang memiliki kualifikasi keahlian dan pengalaman tersebut, serta akan dapat membantu Anda dalam menyusun Spesifikasi Invensi.

Spesifikasi Paten adalah salah-satu dari persyaratan minimum yang harus disertakan dalam mengajukan permohonan paten untuk bisa 
mendapat Tanggal Penerimaan, di samping Formulir Permohonan yang diisi lengkap dan dibuat rangkap empat, dan membayar biaya Permohonan Paten sebesar Rp. 750.000,00. Apabila ketiga persyaratan minimum ini dipenuhi, maka permohonan akan mendapat Tanggal Penerimaan (Filing Date).

Persyaratan lain berupa persyaratan formalitas dapat dilengkapi selama tiga bulan sejak Tanggal Penerimaan, dan dapat dua kali diperpanjang, masing-masing untuk dua dan satu bulan. Persyaratan formalitas tersebut adalah:

- Surat Pernyataan Hak, yang merupakan pernyataan Pemohon Paten bahwa ia memang memiliki hak untuk mengajukan permohonan paten tersebut;

- Surat Pengalihan Hak, yang merupakan bukti pengalihan hak dari Inventor kepada Pemohon Paten, jika Inventor dan Pemohon bukan orang yang sama;

- Surat Kuasa, jika permohonan diajukan melalui Kuasa;

- Fotokopi KTP/Identitas Pemohon, jika Pemohon perorangan;

- Fotokopi Akta Pendirian Badan Hukum yang telah dilegalisir, jika Pemohon adalah Badan Hukum;

- Fotokopi NPWP Badan Hukum, jika Pemohon adalah Badan Hukum; dan

- Fotokopi KTP/Identitas orang yang bertindak atas nama Pemohon Badan Hukum untuk menandatangani Surat Pernyataan dan Surat Kuasa. 
Setelah masa pemeriksaan dilalui dan seluruh persyaratan formalitas dinyatakan lengkap, maka tahap berikutnya adalah Pengumuman. Masa pengumuman akan dimulai $\begin{array}{lll}\text { segera } & \text { setelah } & 18\end{array}$ (delapanbelas) bulan berlalu dari sejak Tanggal Penerimaan, dan akan berlangsung selama 6 (enam) bulan. Memasuki masa pengumuman ini permohonan paten akan dimuat dalam Berita Resmi Paten dan media resmi pengumuman paten lainnya. Tujuannya adalah membuka kesempatan kepada masyarakat untuk mengetahui mengenai invensi yang dimohonkan paten, di mana masyarakat bisa mengajukan keberatan secara tertulis kepada DJHKI jika masyarakat mengetahui bahwa invensi tersebut tidak memenuhi syarat untuk dipatenkan.

Segera setelah masa pengumuman berakhir, atau selambat-lambatnya $\quad 36$ (tigapuluhenam) bulan dari
Tanggal Penerimaan, pemohon dapat mengajukan Permohonan Pemeriksaan Substantif dengan menyerahkan Formulir yang telah dilengkapi dan membayar biaya ke DJHKI. Jika pemohon tidak mengajukan Permohonan Pemeriksaan Substantif dalam batas waktu 36 bulan dari Tanggal Penerimaan tersebut, maka permohonannya akan dianggap ditarik kembali dan dengan demikian invensinya menjadi public domain. Dalam Tahap Pemeriksaan Substantif inilah DJHKI melalui Pemeriksa Paten akan menentukan apakah invensi yang dimohonkan paten tersebut memenuhi syarat substantif sehingga layak diberi paten, berdasarkan dokumendokumen pembanding baik dokumen paten maupun nonpaten yang relevan. Dalam waktu paling lambat 36 bulan sejak Permohonan Pemeriksaan Substantif diajukan, Pemeriksa Paten sudah harus memutuskan apakah akan menolak ataupun 


\begin{abstract}
memberi paten.
Pemohon yang permohonan patennya ditolak dapat mengajukan banding ke Komisi Banding Paten, yang dapat berlanjut ke Pengadilan Niaga hingga akhirnya kasasi ke Mahkamah Agung. Jika pemohon menerima penolakan, ataupun upaya hukum yang diajukannya tetap berujung pada penolakan, maka invensi tersebut menjadi public
\end{abstract} domain.

Terhadap Invensi yang diberi paten, DJHKI akan segera mengeluarkan Sertifikat Hak Paten.

Pengajuan Permohonan Paten bagi sebagian orang mungkin memang melibatkan proses yang sangat panjang dan tidak dapat dikatakan sederhana. Terlebih diperlukan kemampuan khusus untuk dapat menyusun dokumen Spesifikasi Paten yang baik. Untuk itu sangat disarankan bagi para calon pemohon paten
- terutama bagi yang belum berpengalaman - untuk memperoleh bantuan profesional dari Konsultan HKI Terdaftar.

\section{Kapan Sebaiknya Invensi Dipatenkan}

Dalam paten berlaku prinsip first to file, di mana hak paten hanya akan diberikan kepada yang pertama kali mengajukan permohonan paten yang setidaknya sudah dilengkapi syarat minimum pengajuannya, sehingga berhak mendapatkan Tanggal

Penerimaan

(filing date). Dengan demikian, paten bersifat sangat timesensitive sehingga waktu pengajuan permohonan menjadi faktor yang sangat krusial. Konon dalam sejarah, Alexander Graham Bell diakui sebagai inventor telefon hanya karena ia mengajukan permohonan paten setengah jam lebih awal daripada kompetitornya. 
Apalagi syarat substantif paten dari sisi kebaruan (novelty) membuat suatu invensi tidak akan dapat dipatenkan manakala invensi tersebut sudah terlanjur terungkap ke publik sebelum Tanggal Penerimaan permohonannya. Dengan demikian, wajar kiranya jika banyak

orang/lembaga/perusahaan

yang memilih untuk secepatnya mengajukan permohonan paten atas invensi mereka, meskipun mereka belum sungguhsungguh memastikan apakah invensi tersebut memiliki nilai komersial. Bagi banyak pihak, biaya pendaftaran paten yang terbuang untuk sejumlah invensi yang tidak komersial tidaklah seberapa dibandingkan kerugian tidak memilki hak paten atas satu invensi yang bernilai komersial tinggi.

\section{Waktu Dan Biaya Hak Paten}

Satu permohonan dari
mulai penerimaan hingga
pemberian paten bisa memakan
waktu antara 3 hingga 6 tahun.
Sebagai ilustrasi, jika
seseorang mengajukan
permohonan paten dan
memperoleh

Penerimaan 1 Oktober 2014, maka permohonan tersebut baru akan memasuki tahap Pengumuman paling cepat pada tanggal 1 April 2016. Masa Pengumuman akan berakhir pada 1 Oktober 2016. Jika pemohon segera mengajukan Permohonan Pemeriksaan Substantif pada hari yang sama, maka paling lambat pemeriksaan paten akan diputus pada tanggal 1 Oktober 2019. Jika paten diberi, maka masa perlindungan akan berlaku 20 tahun sejak Tanggal Penerimaan yaitu tanggal 1 Oktober 2014, dan berakhir tanggal 1 Oktober 2034. Selama permohonan masih dalam proses, pemohon dapat 


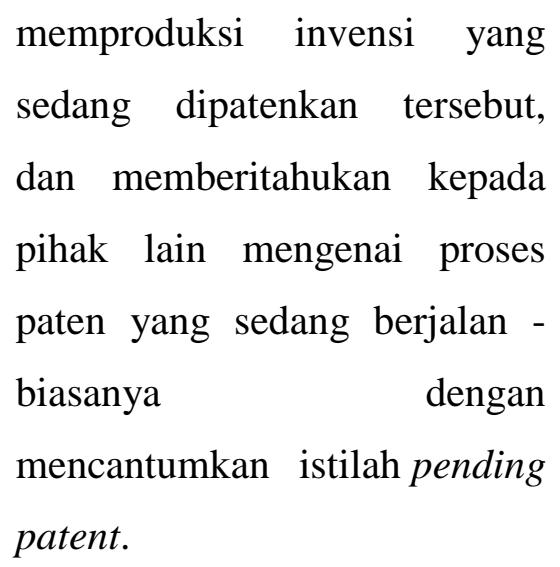

Pemohon tidak dapat mengambil tindakan hukum apapun terhadap pihak lain yang melaksanakan invensi pemohon tanpa ijin selama paten belum diberi dan Sertifikat Paten belum terbit, namun saat setelah Hak Paten diberi Pemilik Paten dapat menuntut ganti kerugian atas pelanggaran paten yang dilakukan sebelum Paten diberi. Dalam ilustrasi di atas, jika ada pihak lain yang melaksanakan invensi tanpa ijin sejak 1 Januari 2015 hingga setelah paten diberi, maka Pemilik Paten bisa menuntut ganti rugi yang dihitung sejak 1 Januari 2015. Komponen Biaya Permohonan
Paten adalah :

- Biaya Permohonan sebesar Rp. 750.000,00 untuk Umum; atau Rp. 450.000,00 untuk UMKM, Lembaga Penelitian, atau Litbang Pemerintah;

- Jika Spesifikasi Lebih dari 30 lembar, maka setiap lembar tambahan akan dikenakan biaya sebesar Rp. 5.000,00;

- Biaya Pemeriksaan Substantif sebesar Rp. 2.000.000,00;

- Jika jumlah klaim lebih dari 10 klaim, maka setiap klaim tambahan akan dikenakan biaya sebesar Rp. 50.000,00.

Tentunya komponen biaya ini belum termasuk biaya jasa profesional apabila permohonan diajukan melalui $\underline{\text { Konsultan HKI Terdaftar. }}$ 


\section{B. CONCLUSION}

Dalam paten berlaku prinsip first to file, di mana hak paten hanya akan diberikan kepada yang pertama kali mengajukan permohonan paten yang setidaknya sudah dilengkapi syarat minimum pengajuannya, sehingga berhak mendapatkan Tanggal

Penerimaan (filing date). Dengan demikian, paten bersifat sangat timesensitive sehingga waktu pengajuan permohonan menjadi faktor yang sangat krusial. Dengan demikian, wajar kiranya jika banyak orang/lembaga/perusahaan yang memilih untuk secepatnya mengajukan permohonan paten atas invensi mereka, meskipun mereka belum sungguhsungguh memastikan apakah invensi tersebut memiliki nilai komersial. Bagi banyak pihak, biaya pendaftaran paten yang terbuang untuk sejumlah invensi yang tidak komersial tidaklah seberapa dibandingkan kerugian tidak memilki hak paten atas satu invensi yang bernilai komersial tinggi.

\section{ACKNOWLEDGEMENT University Of Indonesia University Of Mitra Indonesia Telkom University University Of Mellbourne Saitama University}


A. S. Putra And O. M. Febriani, "Knowledge Management Online Application In Pdam Lampung Province," In Prosiding International Conference On Information Technology And Business (Icitb), 2018, Pp. 181-187.

[2] A. S. Putra, O. M. Febriani, And B. Bachry, "Implementasi Genetic Fuzzy System Untuk Mengidentifikasi Hasil Curian Kendaraan Bermotor Di Polda Lampung," J. Sist. Inf. Dan Manaj. Basis Data, Vol. 1, No. 1, Pp. 21-30, 2018.

[3] O. M. Febriani And A. S. Putra, "Sistem Informasi Monitoring Inventori Barang Pada Balai Riset Standardisasi Industri Bandar Lampung," J. Inform., Vol. 13, No. 1, Pp. 90-98, 2014.

[4] Putra, Arie Setya. "2018 Artikel Struktur Data, Audit Dan Jaringan Komputer." (2018).

[5] Putra, A. S. (2018, July 17). Paperplain Fundamental Create Application With Borland Delphi 7.0 University Of Mitra Indonesia. Retrieved From Osf.Io/Pbrn9. 
Putra, A. S., Aryanti, D. R., \& Hartati, I. (2018, November). Metode SAW (Simple Additive Weighting) sebagai Sistem Pendukung Keputusan Guru Berprestasi (Studi Kasus: SMK Global Surya). In Prosiding Seminar Nasional Darmajaya (Vol. 1, No. 1, pp. 85-97).

Sari, D. P., Febriani, O. M., \& Putra, A. S. (2018, November). Perancangan Sistem Informasi SDM Berprestasi pada SD Global Surya. In Prosiding Seminar Nasional Darmajaya (Vol. 1, No. 1, pp. 289-294).

Putra, A. S. (2018). Paperplain: Execution Fundamental Create Application With Borland Delphi 7.0 University Of Mitra Indonesia.

Putra, A. S., Sukri, H., \& Zuhri, K. Sistem Monitoring Realtime Jaringan Irigasi Desa (JIDES) Dengan Konsep Jaringan Sensor Nirkabel. IJEIS (Indonesian Journal of Electronics and Instrumentation Systems), 8(2), 221232.

Darmawan, A., Yuliawati, D., Marcella, O., \& Firmandala, R. (2016). Sistem Absensi dan Pelaporan Berbasis Fingerprint dan SMS Gateway. EXPLORE, 7(1).

Febriani, O. M., Wahyuni, T., \& Yusuf, S. (2017). DESIGN OF WEBSITE-BASED INFORMATION SYSTEM FOR EDOCUMENT ADMINISTRASI IN THE COMMUNITY SERVICE UNIT (A Case Study at Rajabasa District). INTERNATIONAL JOURNAL OF COMPUTERS \& TECHNOLOGY, 16(7), 7010-7020.
Febriani, O. M., \& Wahyuni, T. (2017, October). PERANCANGAN SISTEM E-DOCUMENT ADMINISTRASI LOGBOOK PENELITIAN PADA UNIT LAYANAN DI BANDAR LAMPUNG. In Prosiding Seminar Nasional Darmajaya (Vol. 1, No. 1, pp. 187-194).

Febriani, O. M., \& Permadi, A. B. (2017). Implementasi Sistem Aplikasi Data Bimbingan dan Pelanggaran Siswa pada Sekolah Menengah Atas di Lampung Tengah dengan Metode Analisis dan Desain Sistem Terdistribusi (SSAD). EXPERT, 7(1).

Febriani, O. M., \& Ambarwati, L. (2015). PERANCANGAN APLIKASI PENGOLAHAN DATA PENJUALAN UKM KELANTING KHAS TELO DESA SIDOHARJO KECAMATAN JATI AGUNG KABUPATEN LAMPUNG SELATAN. Jurnal Teknologi Informasi dan Bisnis Pengabdian Masyarakat Darmajaya, 1(1), 77-95.

Febriani, O. M. (2015). Rancang Bangun Aplikasi Ecommercemenggunakan Freewebstore pada UKM Kelanting di Desa Sidoharjo Lampung Selatan. Prosiding Sembistek 2014, 1(02), 446-458. 